\title{
CONCEPTUAL FRAMEWORK FOR THE LOCALLY SENSITIVE SUSTAINABLE DEVELOPMENT OF PUBLIC SERVICES - CASE STUDY OF THE MUNICIPALITY OF KURŠUMLIJA
}

\author{
UDC 711.27(497.11)
}

\author{
Mihailo Mitković ${ }^{\text {, Biserka Mitrović }}{ }^{\text {, Jelena Djekić }}{ }^{1}$, \\ Petar Mitković ${ }^{1}$, Vladan Nikolić ${ }^{1}$ \\ ${ }^{1}$ University of Niš, Faculty of Civil Engineering and Architecture, Niš, Serbia \\ ${ }^{2}$ University of Belgrade, Faculty of Architecture, Belgrade, Serbia
}

\begin{abstract}
Locally sensitive urban and spatial planning, especially in the domain of the public sector, has been gaining importance lately, and there is almost no document related to the sustainable development which does not emphasize its importance. The reasons for that are numerous - from the need to better adapt the general concepts to the local needs and potentials, to the higher chances for implementation and inclusion of a wider circle of stakeholders. At the same time, the role of public services as an integrating part of urban functions and domains is increasing, as they have a significant role in achieving social integration in the context of urban and territorial development.

In the local strategic plans in Serbia - spatial plans of municipalities - sustainable social development and planning of spatial development of public services represents a significant aspect of planning instruments related to the quality of life, prevention of depopulation, support to the development of the local economy and other. However, the concepts, developmental measures and solutions defined by the spatial and urban plans and strategic documents are often now sufficiently adapted to the appropriate spatial level. In order to contribute to the methodology of planning of social development and public services, this paper presents the approach to the sustainable planning of the spatial development of public services in the framework of the Spatial plan of the local municipality of Kuršumlija, as well as the review of potentials and limitations of implementation of development concept of public services.
\end{abstract}

Key words: Locally sensitive planning, public services, spatial plan, sustainable urban and territorial development, implementation.

Received July 14, 2016 / Accepted November 11, 2016

Corresponding author: Mihailo Mitković

Faculty of Civil Engineering and Architecture, Aleksandra Medvedeva 14, 18000 Niš, Serbia

E-mail: mihailo.mitkovic@yahoo.com 


\section{INTRODUCTION}

Locally sensitive urban and spatial planning, especially in the domain of the public sector, has been gaining importance lately, and there is almost no document related to the sustainable development which does not emphasize its importance. The reasons for that are numerous - from the need to better adapt the general concepts to the local needs and potentials, to the higher chances for implementation and inclusion of a wider circle of stakeholders. At the same time, the role of public services as an integrating part of urban functions and domains is increasing, as they have significant role in achieving social integration in the context of urban and territorial development.

International guidelines, on one hand, emphasize the role of the local level of planning, and on the other hand - revival of public services because of their role in the realization of fundamental social rights of the citizens. Having this in mind, it is particularly important to use the appropriate methodological support to improve planning of the spatial development of public services, starting from the formation of an information basis and assessment of potentials and limitations, through formation of an overall vision and development concept of a local community, to defining measures, instruments and a spatial plan. The context of defining of general and special elements of planned measures and solutions will be specially emphasized in this paper.

\section{INTERNATIONAL GUIDELINES IMPORTANT FOR PUBLIC SERVICES PLANNING}

According to the International Guidelines on Urban and Territorial Planning (UN-Habitat, 2015), urban and territorial (spatial) planning can contribute to the sustainable development so that it is connected with three complementary dimensions of sustainable development: social development and inclusion, sustainable economic growth and environment management and protection. The territorial planning is expected to take into consideration various regional, urban and local situations and the need for a spatially coherent territory and balanced regional development. In addition, it should define, implement and follow decentralization and implementation of policies at all administrative levels and improve the role, responsibility, capacity and resources of the local authorities for planning, in accordance with the international guidelines of decentralization and strengthening of local authorities. On the other hand, according to the same document, the local authorities, in cooperation with other spheres of management and relevant partners, should offer political support for development of urban and territorial plans; they should integrate service delivery into the planning process and take part in the development and financing of housing, infrastructure and public services. In general, the document „Europe in 2020: Strategy for smart, sustainable and inclusive growth” which defines the vision of European social market economy for $21^{\text {st }}$ century, defines social development and development of certain public services as a priority, relying on the concept of smart, sustainable and inclusive economy which provides high employment, productivity and social cohesion (European Commission, 2010). At the same time, the documents of the OECD countries strongly support the development of public services, and which is of special importance, they consider them as an integral set of activities. According to the OECD document „Together for better public services: partnering with citizens and civil society“, public services nowadays play a key role in creation of prosperous and inclusive society, with equal opportunities for all citizens. Now more than ever, the public services are called for to protect the welfare of social communities while simultaneously creating conditions of the 
social and economic development (by strengthening the individuals and communities, improving health conditions, increasing realized education etc.) (OECD Public Governance Reviews, 2011).

However, these and other international documents do not provide sufficiently clear guidelines for full implementation of the principle at the local level. Considering that they are loosely defined so that they could apply to various countries, they leave a potential and an obligation to the governments, local authorities and the professionals to define more precisely locally sensitive measures in instruments for their implementation.

\section{THE VISION OF KURŠUMLIJA MUNICIPALITY DEVELOPMENT}

One of the planning document creating a well-rounded, balanced and sustainable territorial development of the local community is the Spatial plan of the local self-governance unit of (Off. Gazette of Kuršumlija municipality, 6/2015). This plan realized a successful balance between the local needs, potentials, limitations on one hand, and on the other hand, implementation of the principle of international documents related to the sustainable social development and public services development. The vision of development defined by this spatial plan is based on several priorities: (a) affirmation of comparative advantages in relation to the region and the Republic in terms of development of tourism, eco-agriculture, production of sustainable energy and preservation and improvement of the environment; (b) functional integration into the environment with the traffic and infrastructural equipment which is a support and precondition of spatial integration; (c) stable platform for demographic development, by creating conditions for the economic growth, increase and diversification of employment. In this context, as a part of the implementation of this vision, the development and diversification of the public services system are defined, based on the needs of the local population and improvement of their living standard, as well as the special needs related to the tourist activities and visitors.

In the spatial sense, the development belts were defined as well as mutually integrated, but limited urban, rural and natural areas - presented on the Development concept figure (figure 1). The key components of development - primary traffic corridors, settlements which are positioned higher in the hierarchy of settlement network, as well as the key points of tourism, economy and public services development provided by this concept integrate the excessive dispersion of activities and settlements in Kuršumlija municipality.

\section{DEVElOPMENT CONCEPT OF PUBliC SERVICES OF KuRŠUMLIJA MuNICIPALITY}

The general development concept of Kuršumlija municipality in PPJLS Kuršumlija (Official Gazette of Kuršumlija municipality, 6/2015) relies on the development of public services as an important precondition for survival of the settlements and keeping the population. Among the general goals, it was defined that it is necessary to reduce spatial limitation for development of infrastructural and public services network. The following factors stand prominent among the special goals of the Plan as influential factors on the development of public services: a) Optimal activation and stimulation of insufficiently developed areas, for the purpose of reducing differences between the individual regions in the municipality and b) Providing an efficient and rational traffic linking within the municipality and with the other attractive municipalities and regions. 


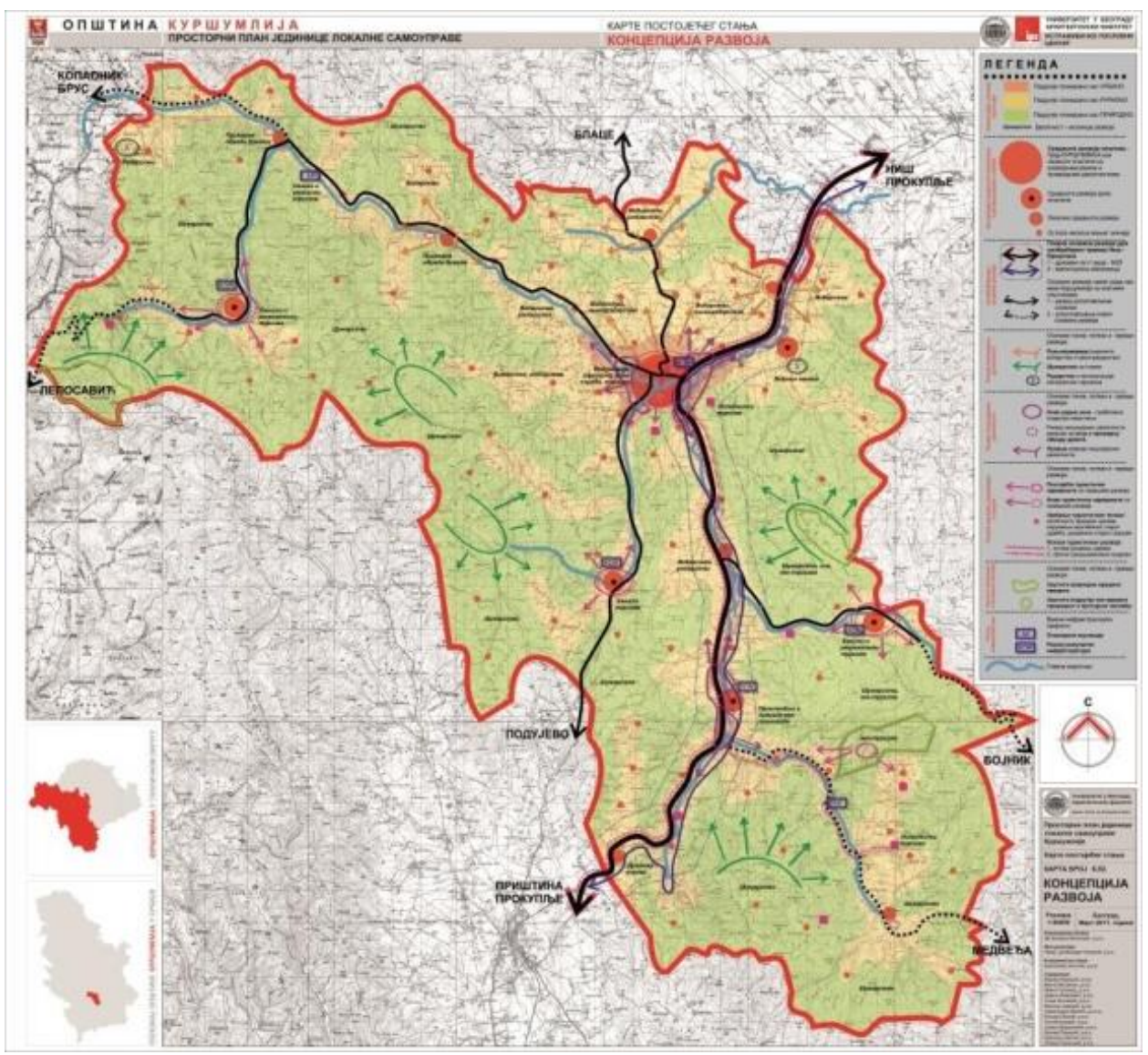

Fig. 1 The concept of the development for Kuršumlija municipality (Source: PPJLS Kuršumlija, 2015)

The general characteristics of the development of public services of Kuršumlija municipality is a relatively good development of the network and high dispersion of the facilities (regarding the large territory of the municipality area), but also a lack of primary services in the small settlements. Such distribution of primary services was mostly contributed by the lack of the developed settlements' network and the structure of their size - i.e. very large number of dispersed, small settlements with a low number of inhabitants. The situation is aggravated by the continuing trend of depopulation, negative birth rate and lack of renewal of the population. The education facilities' network is very dispersed and inefficient, considering the number of children users and depopulation trend in the municipality. The health care facilities are much rarer, while the children care network is almost non-existent having in mind that the only facility is in the settlement of Kuršumlija. The municipality specificity and potential are the presence of Kuršumlijska, Prolom and Lukovska spas, which have developed specialized health care services. 
The development concept of public services is based on the economic, environmental and social cohesion as a contemporary interpretation of sustainable community development, which are among other things characterized by the social progress, quality of life as a most important feature, social equality and other (Mitrović, 2011). The concept of social cohesion was based on providing conditions for satisfaction of needs of diverse groups of the population. Coordination of territorial development results in the consistent territory of the local community, in the reduction of differences between the center and periphery, in the development of secondary centers, in the optimal equalization of the quality of life in the local community and in the contribution to the social and spatial cohesion (Kazepov, 2005). Operationalization of the principle of socially sustainable territorial development should be expressed through the application of the principle of equality, by creating the spatial conditions for minimization of social differences (Mitrović, 2011). Such referential framework represents a precondition for optimum, just and in the same way distributed network of public services which are included in compulsory social care and mostly are not treated as profitable, as defined by the law on Public services ( Off. Gazette RS 1991-94, art. 3).

The future network of public services of Kuršumlija municipality is based on the defined functional threshold which will establish balance between the needs for a better level of equipment of the dispersed settlements, availability and rational organization, and it is based on the principles of equality and justness (Off. Gazette of Kuršumlija municipality, 6/2015). Public services system should recognize the main specificity of the area, primarily those related to the characteristics of the network, size and spatial distribution of settlements, and the presence of specific spa and tourist settlements and places, which require a special approach and specific functions of public services.

Public service network in Kuršumlija municipality must be organized so as to be complementary to the public services of the Toplički district, but also to fully meet the needs of its population, in accordance with its distribution and age structure. This particularly refers to the organization of elementary schools, general health care and preschool facilities. The planning solutions should support the settlements predisposed to become micro-development centers, which can obtain the role of the centers of functional decentralization of the municipality. Their development would provide a balanced distribution of population and a more efficient organization of public services, better coordinated with the needs and interests of the local community. The planned solution of public services in Kuršumlija municipality relies on the following principles:

- Common/integrative action of development of public services on the spatial and total development of Kuršumlija municipality and the tributary area;

- Taking into account the impact of the market, i.e. provision of the conditions for introduction of public services in the domain of private ownership and cooperation of private and public sectors;

- Planning concept is based on the assumption on full implementation of Plan solutions, which comprises cooperation of spatial organization of complementary activities (construction land planning, construction and reconstruction of the road network, etc.).

In the Study of the development of public services on the Kuršumlija municipality territory, made for the needs of the Spatial plan of the local self-governance unit of Kuršumlija (Mitrović, 2013), potential principles of future spatial organization of public services were discussed. On one hand, the principles of rational organization of public 
services would favor «condensation» of settlements and formation of public services points, i.e. concentration in the settlements which were positioned slightly higher in the hierarchy of settlements. In this way, rationality can be provided, and higher economic efficiency but equality in usage and accessibility of services cannot be provided for the entire population. One of the options which could partly overcome this problem about the implementation of fundamental principles is the option of mobile services, where it is rational and possible. In quantitative terms, the implementation of the principle of rationality and efficiency would lead to the reduction of equipment level in public services.

Compensation for such option of the future development should be an increase of the quality of services, better organization and higher efficiency of services with the obligatory and constant monitoring of the fulfillment of needs and realized efficiency. On the other hand, it is possible to retain the existing principle of dispersion which proved in practice to be inefficient, financially requiring and difficult to maintain. As a compromise principle for a part of public services which are prominently dispersed, the principle of settlements' constellation (collective servicing) was implemented (Conyers, 1985).

The concept of public services in Kuršumlija municipality is based on the principles of a) decentralization of basic public services in an equal way, created with the help of citizens' participation to meet the needs, interests and potentials of the community; the main criterion is accessibility of primary public services; b) stimulation of concentration of more complex functions of public services (public governance, administration, culture, media), aiming to strengthen the centrality and attractiveness of the municipality center - Kuršumlija settlement. Planned distribution of public services in PJLS Concept Kuršumlija is defined according to the hierarchical position of the settlements in the network, relying on the above-mentioned criteria and principles:

1) Municipality centre Kuršumlija: planned concentration of secondary levels of different public services, as well as additional equipping of the existing and future parts of the settlement with primary services, aiming to boost the centrality and attractiveness of the settlement.

2) The suburban zones and settlements in the first "ring" around Kuršumlija settlement: the completion of the network of health care and children care facilities; adequate spatial arrangement and completion of the network of mobile and temporary health care services in the settlements of sufficient demographic size; the betterment of elementary education buildings.

3) The centers of the village community: planned conditions for the appropriate spatial distribution of health care facilities across the macro-groups of settlements.

4) Mid-sized villages of the higher hierarchical level: combining the services within the same facility, e.g. future primary healthcare service and/or pre-school education within school buildings, cultural or administration buildings, wherever it is possible.

5) The specialized micro-centers - spa settlements: re-use of the available public facilities which are not rationally utilized for the purposes of functions complementary to tourism and cultural activities.

6) The primary settlements - small villages: the implementation of the model of settlements' constellation (collective servicing), so to avoid concentrating the services in one settlement. The aim is to support the survival and increase of the quality of life in small villages. 


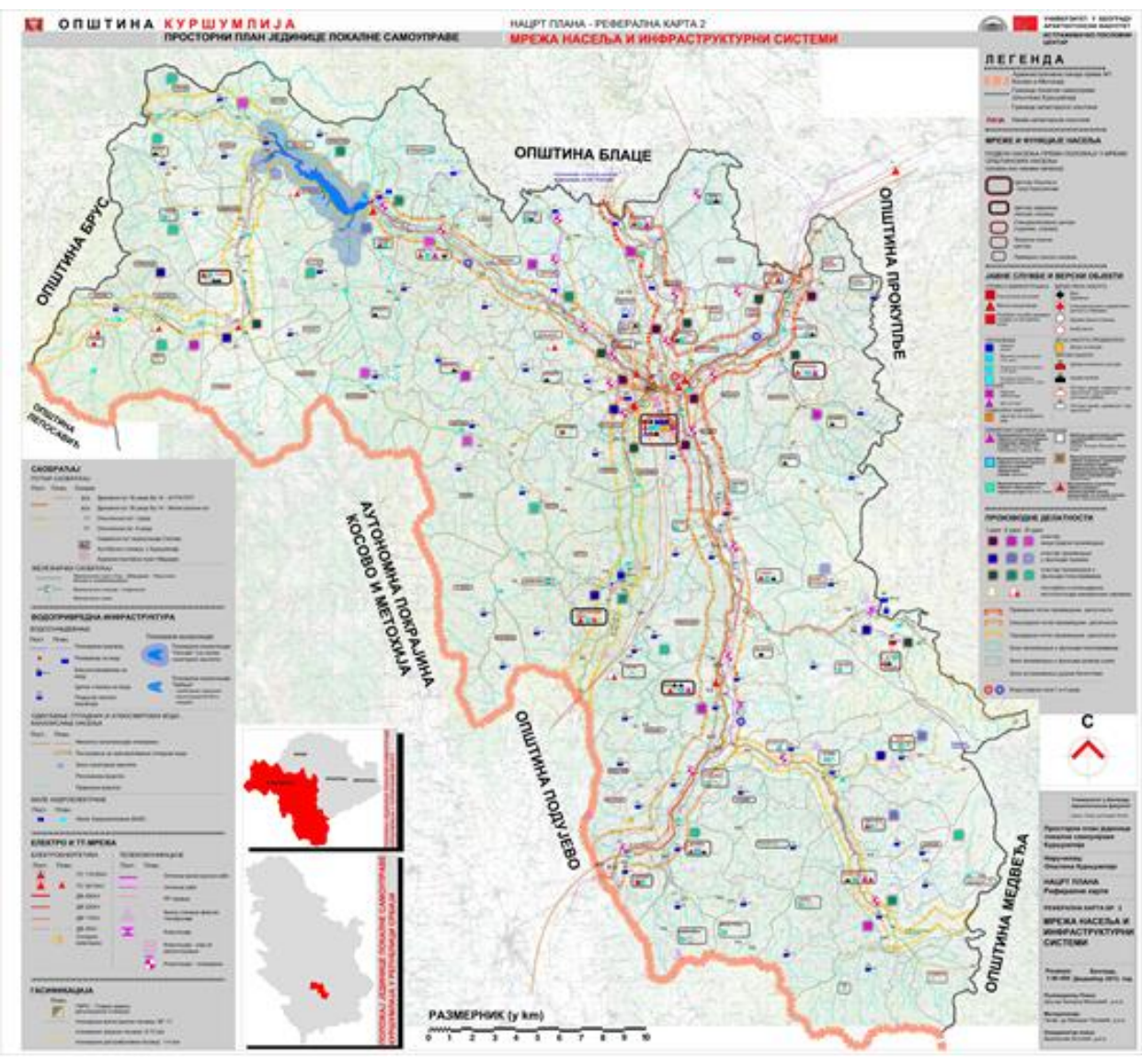

Fig. 2 Referral map no.2, Spatial plan for Kuršumlija municipality (Source: PPJLS Kuršumlija, 2015)

The priorities of implementation of spatial development of public services are primarily related to:

- The concept of development of settlement network aiming to integrate the settlements and improve physical and functional interconnectedness of the settlements, and

- Development of road network and public transport as basic support of the good operation of these services.

\section{CONCLUDING CONSIDERATIONS - POTENTIALS AND LIMITATIONS OF IMPLEMENTATION OF THE CONCEPT OF DEVELOPMENT OF KURŠUMLIJA MUNICIPALITY PUBLIC SERVICES}

The paper emphasizes the importance of planning for the social development and public services in the system of planning in Serbia and potentials and limitations of public services development in the local context with specific characteristics. Considering that the sustainable development has for decades been a premise of the system of planning in the 
world and locally, it is not necessary to stress its importance, but it is necessary to define methodological improvements in this context and at the operative level which would contribute to a better and more realistic implementation of solutions.

The principles and concepts seek to reconcile two ostensibly confronted parties: one is, the current approaches to planning in the context (of still present) transitional changes in Serbia which affect planning of the public sector and aim at rationalization, deregulation and free market action; the other is, local specificity of settlement network, specific requirements and needs of a local community and its population for which it is impossible to plan according to an adopted pattern, even less so if is adopted as model from other environments.

If any country, even those affected by the transition, care about its territory and population, then the priority, which needs to be expressed through the plans, is care for preserving its territory and population, even when it is irregularly or inadequately distributed. Observing it from the standpoint of social development, this means the strengthening of the role and network of public services as one of the mainstays of survival of rural settlements. Investment into the development of various branches of economy - from agriculture and production of healthy food and tourism, which is a very important condition to retain the population, very often is not sufficient. On the other hand, it must be acknowledged that the presented model of the development comes at a high cost, expressed through the preconditions which must be met in order for such a network to be retained and improved. It is primarily the adequate traffic infrastructure which provides accessibility of the services and then equipment level of the buildings and appropriate personnel which would be employed. Outside the spatialfunctional elements of the planning of public services, there is the issue of their uniform treatment in the context of financing and management at the local, and other functionaladministrative levels.

The spatial plan of Kuršumlija municipality, as well as the municipality itself, were chosen as an adequate case study because of its specific characteristics on one hand, and because of typical problems of central Serbia municipalities on the other hand. In this way, the presented findings can be useful in similar situations in research of the development of public services in Serbian municipalities, as well as in the professional practice.

\section{REFERENCES}

1. Conyers, D. (1985) Rural Regional Planning: Towards an Operational Theory, Oxford: Pergamon Press.

2. European Commission (2010): Europe 2020: A European Strategy for Smart, Sustainable and inclusive Growth, Brussels

3. Kazepov, Y.(ed.) (2005) Cities of Europe, changing contexts, local arrangements and the challenge to urban cohesion, London :Blackwell Publishing

4. Mitrović, B. (2011) (Ne)održivo lokalno planiranje u čeljustima tranzicije: sudbina sportskih i rekreativnih površina u praksi planiranja u Beogradu, Nauka+Praksa, str. 47-51 14/2011., Građevinskoarhitektonski fakultet, Univerzitet u Nišu.

5. Mitrović B., Mitković P, Antonić B. (2013): Studija koncepcije razvoja opštine Kuršumlija, radjena za radjena za potrebe izrade Prostornog plana jedinice lokalne samouprave Kuršumlija, Beograd: Arhitektonski fakultet

6. Mitrović B. (2014) Studija razvoja javnih službi na teritoriji opštine Kuršumlija, radjena za potrebe izrade Prostornog plana jedinice lokalne samouprave Kuršumlija, Beograd: Arhitektonski fakultet

7. OECD (2011) Together for Better Public Services: Partnering with Citizens and Civil Society Public Governance Reviews, retrieved from: http://www.oecdbookshop.org/browse.asp?pid=titledetail\&lang=en\&ds=\&ISB=9789264118843 
8. UN HABITAT (2015) International Guidelines on Urban and Territorial Planning, United Nations Human Settlements Programme, Nairobi

9. Prostorni plan jedinice lokalne samouprave Kuršumlija - (,S1.list opštine Kuršumlija“,br. 6/2015)

10. Zakon o izmenama i dopunama Zakona o planiranju i izgradnji (Službeni glasnik RS 121/12).

11. Zakon o javnim službama (Sl. glasnik RS, 42/91, 71/94.)

12. Zakonom o planiranju i izgradnji (Službeni glasnik RS 72/09, 81/09 - ispravka, 64/10, 24/11 prečišćen tekst).

\section{KONCEPTUALNI OKVIR ZA LOKALNO OSETLJIVO PLANIRANJE JAVNIH SLUŽBI NA PRIMERU OPŠTINE KURŠUMLIJA}

Lokalno osetljivo urbano i prostorno planiranje, posebno u domenu javnog sektora poslednjih godina dobija na značaju i gotovo da nema dokumenta vezanog za održivi razvoj koji ne naglašava njegov značaj. Razlozi su brojni - od potrebe da se generalni koncepti bolje prilagode lokalnim potrebama i mogućnostima, do veće šanse za implementaciju i za uključivanje šireg kruga aktera. Istovremeno raste i uloga javnih službi kao integrišućeg dela urbanih funkcija i domena koji ima značajnu ulogu u dostizanju socijalne integracije u kontekstu urbanog i teritorijanog razvoja.

U lokalnim strateškim planovima u Srbiji - prostornim planovima opština održivi socijalni razvoj i planiranje prostornog razvoja javnih službi predstavlja značajan aspekt planskih mera vezanih za kvalitet života, sprečavanje depopulacije, podršku razvoju lokalne ekonomije i drugo. Medjutim, koncepti, razvojne mere $i$ rešenja definisani prostornim i urbanističkim planovima $i$ strateškim dokumentima često nisu dovoljno prilagodjeni odgovarajućem prostornom nivou.

Sa ciljem doprinosa u domenu metodologije planiranja socijalnog razvoja i javnih službi, $u$ radu je prikazan pristup održivom planiranju prostornog razvoja javnih službi u okviru Prostornog plana jedinice lokalne samouprave Kuršumlija, kao $i$ pregled mogućnosti $i$ ograničenja implementacije koncepta razvoja javnih službi.

Ključne reči: lokalno osetljivo planiranje, javne službe, prostorni plan, održivi urbani i teritorijalni razvoj, implementacija. 